\title{
Error Analysis in article
}

\author{
Zirui Liu \\ Shaanxi vocational and technical college, 710010, China
}

Keywords: analysis errors; article; SLA.

\begin{abstract}
This paper analyses actual errors coming from a Chinese learner of English as her second language. To compare with other errors in English learning, grammatical errors are more serious than others because of misunderstanding. Error analysis would be reveal the developmental features of Chinese students using article in written passages and how this affects students learning a foreign language. The purpose of this assignment is to improve the quality of error feedback to language learners, in order to help us make sense of the nature of SLA. There are six parts: (1) Background (2) Methods (3) Data analysis (4) Results (5) Discussion (6) Conduction.
\end{abstract}

First language acquisition effects the study of second language. In early 1973, Oller and Richards revealed the influence of first language acquisition research on second language acquisition (SLA) research can be used in the error analysis approach. After two years, Schumann and Stenson (1975) noted similarities between the types of errors reported in the first language acquisition literature and the errors made by SLA. On the basis of this similarity, researchers speculated that the processes of first and second language acquisition are essentially the same (Corder 1967; Dulay \& Burt, 1972; Richards, 1973). In order to have a deeper understanding of the grammatical morpheme underlying SLA, such as article, it is essential to analyze actual errors of articles among language learners.

Interlanguage (IL) can be defined as the language system of L2 learners during the process of learning or acquiring the target language which is independent of both the target language and the learner's L2 (Lightbown \& Spada, 2006). The term introduced by Selinker (1972) to refer to the systematic knowledge of an L2. It. For example, translating Chinese into English can hardly be direct, thus it needs assistance from medium language. In addition, he also emphasized the notion that learner`s language is systematic by suggesting the term "IL" to refer to the learner's developing L2 system. People learn foreign language would be supported by fossilization and backsliding following with age increased.

"IL variation can be defined as the tendency for an L2 learner's utterances, or language production such as in the form of speaking and writing, to vary systematically in the accuracy of not only linguistic forms, but also pragmatic discourse, sociolinguistic and strategic forms as situations change, e.g. specific features of situational context and task ." Ellis (1994, p. 89)

Most Chinese learner study English grammar rules based on Chinese grammar rules in context where there are not applicable, because Chinese grammar does not have distinguished to express specified or unspecified things. That is why Chinese learners are preferred to learn article based on grammar instruction rather than dynamic learning article. They just fix grammar rules in the book and learn English rules in a Chinese way because instruction was based on Chinese English fashion.

This assignment discusses the actual errors of article in language learning and identifies what sociolinguistic variables are problematic for Chinese learners and how those variables affect the types of articles to SL in their learning, such as omission, wrong match and so on. Generally, errors are divided into two categories: interlingual and intralingual errors (Phakiti, 2009). For example, interlingual errors can be traced back to the native language of learner, such as a Chinese student wants to express plural noun. In Chinese grammar, it changes figures when describing more than one item. Intralingual errors arise from the target language and can be found among children learning it as their first language. The examples show one Chinese learner and a native English speaker use article in his or her daily life (Jxenglishnet, 2009): 


\begin{tabular}{|c|c|}
\hline English speaker & Chinese student \\
\hline $\begin{array}{c}\text { I decided to climb a tree to see where we were. } \\
\text { After an hour or so we began to feel very } \\
\text { frightened. }\end{array}$ & $\begin{array}{c}\text { I decided to climb the tree see where we } \\
\text { were. }\end{array}$ \\
\hline $\begin{array}{c}\text { After an hour or so we began to feel very } \\
\text { frightened. }\end{array}$ \\
\hline
\end{tabular}

The regularities of article can be divided into 3 parts, definite article (the), indefinite article (a and an) and zero article (0). According to English Grammar Lecture Series(3), it can be known that: Indefinite Articles using (1) before countable nouns, such as a car; (2) Signifies nouns that are generic in nature, such as a pig has four legs; (3) before singular nouns only, never plural, such as a piece of cake; (4) an before nouns starting with a vowel sound, such as an apple; using a before nouns starting with a consonant sound, such as a piano; (5) An is used with words in which the $h$ is silent, such as an hour. A may be used when the $\mathrm{h}$ is pronounced, as in a horrid example. A is used with $\mathrm{u}$ when it sounds like yew, as in a union, and with o as in a one-way street; (6) with initials, pronunciation determines the article. Such as an SAT test and in a BBC program. Definite Article using (1) with nouns that are specific in nature (countable or mass, singular or plural), such as, President Clinton lives in the White House; (2) when there is only one of something, such as the moon; (3) with superlative forms of adjectives, such as the fastest; (4) a particular item or just one instance, such as the books for my course are expensive; (5) when the noun has just been mentioned, such as I have a pen and a pencil. The pencil is broken; (6) before the names of musical instruments, such as she plays the flute. Zero article when (1) the destination implies the activity, such as we go to bed (meaning to sleep); (2) in front of geographical names, except bodies of water and mountain ranges; (3) in front of countries` name which contain the words "union" or "united", such as the Soviet Union.

Hence, the study of learner language development is a key and crucial area of investigation in SLA. The followings will describe and discuss research findings through data collection to figure out possible reasons affecting the learner`s accuracy in article use in English learning second, the question of when they are required, as well as how they are required by this learner.

\section{Methods}

This research focuses on the error analysis of article in one Chinese learner of English as her second language. She was 19 year old and just arrived in the Australia three weeks prior to the onset of data collection. She has received six years of English instruction in China. However, she indicated that her training had been primarily in reading and listening, and that she had little practice in grammar and writing. She enrolled in the summer intensive English and orientation program at the language centre in university upon her arrival in the Australia. On the basis of her English test score, she was placed in the beginning level of instruction.

Data were collected during 20 to 30 minutes sessions every ten days for a period of one month. Because article describes a link with a noun or noun phrase, therefore, she was asked to write three essays, one for her favorite story, one for the most important transportation in China and one for her ideal job. The process of data collection should consider 2 points. Firstly, it only asked her to write three essays about the most important transportation in China, her ideal job and one story for childhood, instead of telling her anything about the research. Secondly, it should ensure student is in a relax environment of writing. This method of data collection has three advantages: (1) because the student was not aware of that she was being tested, she was less self conscious about her knowledge of article; (2) her essays were less distracting because she was engrossed in the task of writing essays; (3) student who left alone without the presence of the researcher was more likely to feel relax. One disadvantage of the data collection method is that there is no guarantee that all the necessary types of article usage for the comparison study would be elicited. However, the result of this research was very successful in eliciting the necessary types of article use through the three essays written by the examinee. 


\section{Analysis of the data}

In order to have a great understanding of the processes in using article underlying interlanguage development, it is essential to use methods of analysis that can adequately uncover those processes.

"Huebner (1984) has developed a system of analysis that accounts for article use in all contexts, that is to say, in all pre-noun positions. The system describes two things: (1) the semantic function of each noun phrase used with that NP function and (2) the ways in which this article + NP function changes over time. To determine with what accuracy articles are used, one considers what is used in Standard English: definite article, indefinite article and zero articles." (p 214)

From her three passages, it was easier to see that her errors in article can be divided into three parts, one is omission and rests are wrong match and special rules.

\begin{tabular}{|c|c|c|c|}
\hline & Definite & Indefinite & Zero Definite \\
\hline Omission & 2 & 1 & 0 \\
\hline Wrong match & 2 & 2 & 5 \\
\hline Special rules & 1 & 0 & 1 \\
\hline
\end{tabular}

The errors come from omission

China, as one of developing countries, has no financial potential to expand its roads and to manufacture so many cars to satisfy the need of so many Chinese.

Two long vacations offer an opportunity for reflection, research and writing.

Moreover, I have opportunity to keep on learning.

The errors come from wrong match

Bicycles, as the means of transport, are indispensable companions of most Chinese.

Compared with the cars, bicycles, however, have their own distinctive advantages.

There are the various kinds of jobs in world.

I have made up my mind to be the teacher chiefly for three reasons.

They often find the large catlike tracks along the ground.

The most animals have the favorite food.

They have the great courage and the strength in a group.

I like a pace of the academic calendar.

A Jaguar and the wild pig.

Bicycles will remain to be a important means of transport in China in the many years to come.

more and more Chinese will own an car though cars will never completely substitute bicycles in the future.

The errors come from special rules

These tracks are made by the spotted jaguar, the greatest hunter of all the North American continent.

There are the various kinds of jobs in world.

\begin{tabular}{|c|c|c|c|}
\hline \multirow{3}{*}{ Correct } & Definite & 2 & Subtotal \\
\cline { 2 - 3 } & Indefinite & 5 & 8 \\
\cline { 2 - 3 } & Zero Article & 1 & \\
\hline
\end{tabular}

The results not only showed her errors mainly came from omission, wrong match and special rules, but also look at her correct usage of articles.

\section{Results}

From the data, this student has committed intralingual or development errors, mostly originating from overgeneralization. 
Table 1: the types of error in article

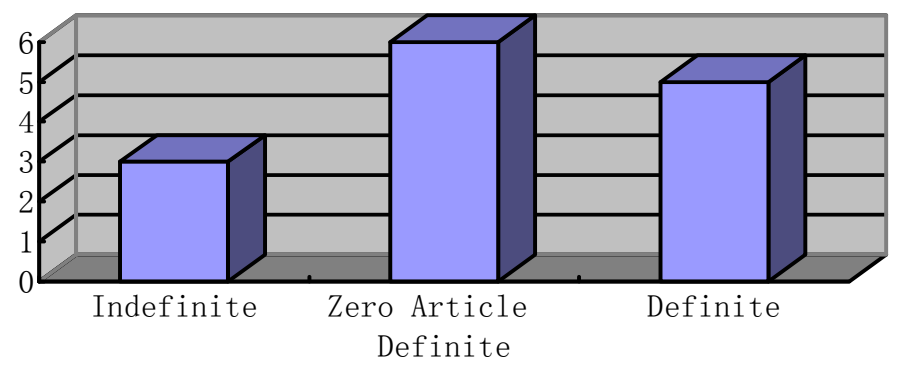

$\square$ Article

The table showed various types of errors in article usage in her essay. It can be clearly seen that student was the worst in Zero Article (6), and then Definite Article (5) and Indefinite (3). The number of errors in Zero Article doubled compared with those in the number of errors in Indefinite. The number of errors in Zero Article and Definite were similar.

Table 2: the numbers of correct and incorrect article in her essays

\begin{tabular}{|c|c|c|c|c|}
\hline \multirow{3}{*}{ Correct } & Definite & 2 & Subtotal & Total \\
\cline { 2 - 3 } & Indefinite & 5 & 8 & \\
\cline { 2 - 3 } & Zero Article & 1 & \\
\hline \multirow{3}{*}{ Incorrect } & Definite & 6 & \multirow{2}{*}{14} \\
\cline { 2 - 3 } & Indefinite & 3 & \\
\cline { 2 - 3 } & Zero Article & 5 & \\
\hline
\end{tabular}

From the table 2, it can be seen that her used 22 times articles in her 3 essays including 8 times correct form (definite 2, indefinite 5 and zero article 1) and 14 times incorrect (definite 6, indefinite 3 and zero article 5). She was good at indefinite while poor in definite and zero article. The total number of correct forms is less than half of the numbers of the incorrect forms.

Table 3: the length of learn at the language center affect the learner's article knowledge

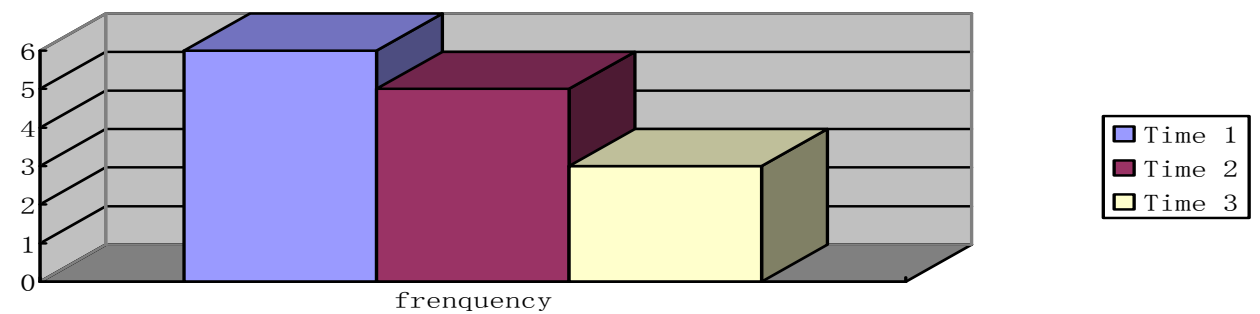

Table 3 showed that after she systematically learnt article at language center, her errors decreased dramatically from 6 to 3 in one passage.

Based upon the errors that Chinese learner met, I believe her errors belong to intralingual. Comparing with Chinese grammar which does not have articles in written or spoken, her errors originated from the language being learnt and depended on her own learning system. It did not link with her first language grammar rule, Chinese. For example, I have a book and I have two books. In Chinese, only the digit has to be changed, no more any other changes in the sentence.

\section{Discussion}

All of these errors reflect the learner's own understanding of the second language system, rather than an attempt to transfer characteristics from her first language. These errors are called developmental errors or the errors of overgeneralization. Sometimes, it is described as simplication when some elements are left out (Phakiti, 2009). As can be seen from Table 1 and Table 2 many 
errors are common in following occasions: (1) it should use definite article to express specify (e.g. China as one of the developing countries), something unique (e.g. the United States), superlatives (e.g.The most animals have a favourite food); (2) it should use zero article to express names, countries, festivals, days, etc. (e.g. the greatest hunter of all North American continent.), abstract nouns (e.g. I like the pace of the academic calendar.), uncountable and plural countable nouns (e.g. There are various kinds of jobs in the world); (3) it should use indefinite article to express unspecified thing (e.g. I have made up my mind to be a teacher chiefly for three reasons.), job (e.g. a teacher) and frequency (e.g. it costs $£ 3$ a meter).

The results of analyzing the relationship between the length of learning at the language center and the learner's article knowledge have been displayed in Table 3. Chinese learner of English as second language who has learnt at language center in Australia longer time proves she can better deal with grammatical phenomenon in her essays. The result supports Beebe and Takahashi`s (1986) hypothesis:

"In order to find out the relationships between length of residence and pragmatic transfer, the ratios of the strategy selections were compared ..... Hence, Hypothesis 3 (Assimilation will be correlated to the length of residence in Japan) was strongly supported. It should not be forgotten, however, that an even longer stay in Japan led to the hypercorrection and many of the subjects" (p. 154)

The proficiency level and the exposure time to the English grammar rule seem to increase the amount of grammar transfer. It appears that the higher her proficiency is, the less they resort to formulaic patterns and the more she can appreciate English article and feel competent to attempt complex article rule expression in her essays that expresses her identity with her L1 grammar.

Morpheme acquisition can help people predict stages of article study. The aim of future stages would help student determine what accurate articles should be used. For example, firstly, learner should know how many standard articles used in English, such as, definite, indefinite and zero article; secondly, what the rules for definite rules are, what the rules for indefinite are and what the rules for zero article are; thirdly, what the special rules are, such as idioms and commonly used expressions or it eliminated second and subsequent noun phrases in a series.

According to Williams (1996), it can be known that some of the methods have been used in teaching article from direct and cognitive code learning. The specific objectives will determine the choice of a method to use. Therefore, people believe there is no teaching method that has only merits without demerits on second language learning. As an English teacher, one can be teaching article in a flexible and eclectic way. For example, teaching article in English should go along with the teaching of noun or phrases. It is usually better to start from the morpheme on the rank scale as this will enable students to develop adequate linguistic expressions from the scratch. Any attempt to teach article in isolation will lead to the enhancement of the linguistic competence of the students at the detriment of their communicative competence because of dynamic and unaccounted language. What is more, if possible, it should thoroughly teach and introduce to students earlier in their English course, because the introduction course has to be gradual and should start with units from the morpheme to the sentence. The last suggestion is teaching article needs to up-to-date knowledge of article rules. This is very essential especially in china where students significantly depend on teacher`s instruction.

\section{Conclusion}

To sum up, this study has revealed that student's knowledge of the mastery of English article was grossly deficient and inadequate. First language acquisition directly and indirectly effect second language acquisition. From one Chinese student sampled for this study, she was poor in article morpheme in her written essay. The student's knowledge of the article was largely concentrated on those that begin with any of these "a"," "an", "the" and " 0 ". For effectively teaching of article, the eclectic method of teaching should be preferred which will enable students to be exposed to choose the appropriate the various types of articles. The students need to be exposed to the linguistic expressions at the various levels on the rank scale especially as Muir (1972:15) notes that for 
methodological consistency and convenience, it will be directly convenient in morphological considerations to also consider the "word" because linguists are always concerned with these units on the rank scale.

\section{References}

[1] Beebe, L.M., Takahashi, T., \& Uliss-Weltz, R. (1990). Pragmatic transfer in ESL Refusals. In R. Scarcella, E. Andersen \& S. Krashen (Eds.). Developing communicative competence in a second language (pp. 55-73). Boston, MA: Heinle \& Heinle. Brown, R. 1973. A Firsr Language. Cambridge, Massachusetts: Harvard Press.

[2] Dörnyei, Z. (2001). New themes and approaches in second language motivation research. Annual Review of Applied Linguistics, 21, 43-59.

[3] Doughty, C., \& Long, M.H. (Eds.) (2003). Handbook of second language acquisition. Oxford: Blackwell.

[4] Ellis, R. (1994). The study of second language acquisition, Chapter 2 Oxford: Oxford University Press.

[5] English Grammar Lecture Series(3), Accessed Date: $23^{\text {rd }}$ Oct. 2009

[6] http://emuch.net/journal/article.php?id=CJFDTotal-YYZX199609011

[7] Jxenglishnet (2009), Article mistakes in English exam, Retrieved October 21, 2009 from: http://www.jxenglish.com/Article/proofreading/10924.html

[8] Huebner, T. 1979. Order-of-acquisition vs. dynamic paradigm: a comparison of method in interlanguage research. TESOL Quarterly, I3:21-28.

[9] Lightbown, P.M. (2000). Anniversary article: Classroom SLA research and second language teaching. Applied Linguistics, 21, 431-462.

[10]Lightbown, P.M. \& Spada, N. (2006). How languages are learned (3nd ed.), Chapter 4, 57-59, Oxford: Oxford University Press. 